\title{
TRANSLATION METHODS AND PROCEDURES IN BILINGUAL STORYBOOKS
}

\author{
Arif Hidayat; Danang Dwi Harmoko
}

Program of English Education, STIBA Nusa Mandiri

Jl. Ir. H. Juanda No. 39, Ciputat, Tangerang Selatan

arif.aft@nusamandiri.ac.id, dnd.marketer@gmail.com

\begin{abstract}
This research is aimed at finding the procedures and method of three bilingual storybooks. The research method used is descriptive qualitative with content analysis. Based on the theory of Newmark about translation method and procedures, it is found that the frequently used procedures are literal, modulation, shift, addition and reduction. The translation on the first book indicated that the translator uses shift modulation, couplet, cultural equivalent, addition. In the second book, the procedures used are literal, addition, modulation, reduction, transference, expansion and couplet. Whilst, in the third book, there couplet, literal, addition, reduction, modulation, cultural equivalent, shift, synonymy, expansion procedures are found. On the other hand, the most dominant procedure used is literal and the translation method used is semantic translation. The method shows the translation orientation of the translators.
\end{abstract}

Keywords: translation procedures, translation method, Newmark, bilingual storybooks

\begin{abstract}
ABSTRAK
Penelitian ini bertujuan untuk menemukan prosedur dan metode dari tiga buku cerita dwi bahasa. Metode penelitian yang digunakan adalah deskriptif kualitatif dengan analisis isi. Berdasarkan teori Newmark tentang metode dan prosedur penerjemahan, ditemukan bahwa prosedur yang sering digunakan adalah literal, modulasi, pergeseran, penambahan dan pengurangan. Terjemahan pada buku pertama menunjukkan bahwa penerjemah menggunakan pergeseran modulasi, bait, penyetaraan budaya, penambahan. Dalam buku kedua, prosedur yang digunakan adalah literal, penambahan, modulasi, reduksi, transferensi, ekspansi dan penggandengan. Sementara itu, di buku ketiga, ada bait, literal, penambahan, pengurangan, modulasi, penyerataan budaya, pergeseran, sinonim, prosedur ekspansi ditemukan. Disisi lain, prosedur yang paling dominan digunakan adalah literal dan metode penerjemahan yang digunakan adalah terjemahan semantik. Metode ini menunjukkan orientasi terjemahan para penerjemah.
\end{abstract}

Kata kunci: prosedur penerjemahan, metode penerjemahan, Newmark, buku cerita dwi bahasa 


\section{INTRODUCTION}

Along with the more blended people living in one place and more mobile people from one place to another, communication is getting more complex and complicated. Therefore, international languages such as English, Chinese and Arabic are used to be the bridge of communication. For this reason, too, many people realize that they have to prepare themselves and their children with one or more international language(s).

As a type of books, bilingual storybook has a function to entertain. By sending the message through its plot added with the ingredients of joy, sad dramatic and/action scenes in it. However, nowadays, storybooks taking this as a chance to become entertainment and learning media at once due to the needs of international languages.

In accordance to the bilingual storybooks, translation plays a good deal on the works as to convey the story into another language. Regarding to this, Newmark, as quoted by (Hoed, 2005), stated that translators have responsibility on the written, bilingual and international communication, between author and the readers. They have the responsibility on giving the truth of the source text message as what Larson (Wuryanto, 2005) and (Sundari \& Febriyanti, 2016) says that the meaning must be transferred constantly and proportional.

In order to transfer the message of the story to the readers, there are some procedures, methods, strategies and techniques given by many experts. One of the experts is (Newmark, 1988). He mentions seventeen procedures and eight methods of translation. The procedures are:

1. Literal

2. Transference
3. Naturalization

4. Cultural Equivalent

5. Functional Equivalent

6. Descriptive Equivalent

7. Synonymy

8. Through Translation

9. Shift or Transposition

10. Modulation

11. Recognized Translation

12. Translation Label

13. Compensation

14. Reduction and Expansion

15. Paraphrase

16. Couplets

17. Notes, Addition, Glosses

Whilst, the methods are word to word, literal, faithful, semantic, communicative, idiom, free, and adaptation. The methods of translation exposed by Newmark are in the level of text while procedures are level of sentences or in the smaller unit: words and/or phrase.

The procedures and methods of translation done by translators are important to send the message. The ideology of translators, whether to be faithful to the source or the target readers, will play an important role in choosing the methods of translation.

\section{METHOD}

This research is aimed at finding the procedures and method of translation adopted by translators. The sub-focus that may be entailed is the ideology of the translator that made them taking the procedures and methods. Descriptive qualitative research is chosen as the method of the research by adopting the technique of content analysis of Klaus Kripendorf (Emzir, 2010) where this technique is to build replicable and valid implication/conclusion. Whilst, source of data taken in this the research are the following story books: 
1. Animal Around Us: Butterfly

2.Seri Mengenal Hewan Cerita Si

Laba-Laba, and

\section{Julie di Peternakan}

The data themselves are all the sentences in the source and target texts. To analyze the data using content analysis, Marrying (Titscher, 2009) mention nine steps of procedures:

1. Material decision

2. Source text situation analysis

3. Material characterization formally

4. Analysis direction decision
5. Differentiation of the questions to ask based on the theory (ies) used

6. Analysis techniques selection (order explication summary)

7. Analysis unit definition

8. Material analysis (order explication summary)

9. Interpretation

In the process number 5, the researcher takes the translation procedures and method given by Newmark in the form of the following sample instrument to help:

\begin{tabular}{llllll}
\hline No & \multirow{2}{*}{ Storybooks } & $\begin{array}{l}\text { Source } \\
\text { Text }\end{array}$ & $\begin{array}{l}\text { Target } \\
\text { Text }\end{array}$ & $\begin{array}{l}\text { Translation } \\
\text { Procedures }\end{array}$ & $\begin{array}{l}\text { Translation } \\
\text { Method(s) }\end{array}$ \\
\hline 1 & Storybook 1 & Sentence 1 & Sentence 1 & Procedure? & \\
2 & & Sentence 2 & Sentence 2 & Procedure? & Method ? \\
3 & & Etc & Etc & Procedure? & \\
4 & Storybook 2 & Sentence 1 & Sentence 1 & Procedure ? & \\
5 & & Sentence 2 & Sentence 2 & Procedure? & Method ? \\
6 & & Etc & Etc & Procedure? & \\
7 & \multirow{2}{*}{ Storybook 3 } & Sentence 1 & Sentence 1 & Procedure? & \\
8 & & Sentence 2 & Sentence 2 & Procedure? & Method ? \\
9 & & Etc & Etc & Procedure? & \\
& & & & &
\end{tabular}

\section{RESULTS AND DISCUSSION}

This part will discuss the following data are the examples of this category.

procedures and methods of each storybooks being the sources of data i,e 'Animal Around Us' (Sasongko, 2007), 'Cerita Si Laba-Laba' (Haryani, 2010), and '...'.

1. Animal Around Us: Butterfly

There are 35 data found in this storybook. Among the data, it is found that the procedures found in the source of data are literal, shift modulation, couplet, cultural equivalent, addition.

\section{Literal}

There are nine data categorized as literal procedure found in the storybook Animal Around Us. The data are concluded as literal because the translator translate it literally without giving any changes to them. The

Datum 5

SL: Suatu hari, aku bertemu kakekku

TL: One day, I met my grandfather

Here, we found that the datum is translated literally to the target language. Though the source language bertemu is translated as met, there is not any change since the context is past tense where it happened before. Another example can be seen in datum 23:

SL: Beberapa hari kemudian ulat itu berubah.

TL: Few days later the caterpillar changes.

As in the previous example, the TL does not have any changes. It uses simple present tense since it is a fact information, 


\section{Shift}

Among the data, there are about fourteen data are included as shift procedure; The shift ranges from the changes from plural to singular, the changes of structure and the changes of the parts of speeches. The followings are the examples of translation shift found in the data:

Datum 6

SL: Kakekku bercerita kepadaku tentang kehidupan kupu-kupu

TL: He told me about the life of butterfly

Here in this datum, the translator changes the source word kakekku with the target language 'he'. The changes is done since the word 'he' refers to kakek (the grandfather of the character telling the story) which has been mentioned earlier so that it doesn't give redundancy and it won't change the meaning convey to the readers.

Another example is datum number 14 as the following:

SL: Racun gatal itu berfungsi sebagai alat perlindungan bagi ulat.

TL: The itchy poison has a function as a protector.

The target language sentence indicates the change of part of speech happens to the source word berfungsi into 'a function'. This shows that the author change verb (berfungsi) into noun (function). It is the category of class shift.

However, there are two shift procedure sentences causing changes on the meaning. The changes are detect of the different structure tenses. Theses sentences are the data number 2 and 3 . The sample is the datum 2 as the following:

SL: Aku terbang ke taman-taman dan pepohonan untuk mencari bunga.

TL: I am flying around the parks and trees to get flower.
In the source language, the structure tense is in the present tense. While, the translated version is in the form of progressive. We can see that the source language sentence shows the habitual action or fact done by butterflies daily/habitually. It is different to the translated version which shows something in process.

\section{Modulation}

There are five modulation procedure found among the data, the translator wants to show us the different point of view through the modulation procedure he has done as the following example:

Datum 4:

SL: Karena makanan kupu-kupu adalah sari bunga.

TL: Because my food is flower's essence.

Datum 4 display the changes of makanan kupu-kupu into 'my food'. The changes shows the different point of view of the story teller: third person into the first person. The source language text indicates the position as the third person telling the story. Whilst, in the target language, the position of the story teller is being the first person (the young butterfly). The changing of point of view can also be seen in datum 9:

SL: Sepuluh hari kemudian kulit kepompong retak

TL: After ten days the cocoon's skin cracks

The translator changes the source phrase Sepuluh hari kemudian into 'After ten days'. He wants to show that the phrase sepuluh hari kemudian which can literally be translated as 'ten days later' are possible to translate as 'after ten days' without changing the meaning.

\section{Addition}


Two additions are found in the data. The addition procedure are found in datum 32 and datum 33,

Datum 32

SL: Itulah yang disebut dengan metamorfosis.

TL: This is what we called metomorphosis.

In datum 32, the author add target word 'we' in the translation. He adds the word to complete the active sentence. Meanwhile, the following is datum 33:

SL: Metamorfosis adalah perubahan bentuk.

TL: Metomorphosis is a process of changing shape.

Here in datum 33, the translator adds the target word 'process of'

\section{Cultural Equivalent}

Cultural equivalent procedure is also found among the data. The cultural equivalent procedure can be seen in datum 7 as the following:

Datum 7

SL: Wah, aku senang sekali.

TL: Wow, I was very happy

There is an interjection which is related to Indonesian culture in the source language: wah. This interjection then is translated with the suitable interjection in target language: 'wow'.

\section{Couplet}

There are two couplet procedures found in the data. The translator combine two or more procedures in one translation sentence. The couplet procedure is in datum 8 and datum 19.

Datum 8

SL: Sepasang pengantin kupu-kupu meletakkan telur-telur sang betina di daun.

TL: A couple of butterfly lay their eggs on a leaf.

In datum 8 , the translated version has two types of translation procedures: reduction and modulation. The reduction happens in the first phrase of the source sentence: 'sepasang pengantin'. The translated version is only in the form of 'a couple'. Meanwhile, the modulation happen in the translated version of telur-telur sang betina into 'their eggs'. The translator wants the translated version readers view that the eggs belong to the spouse, not only the female.

\section{Error Data}

Despite the procedures found above, there are two data rejected to analyze. It happens since the data don't fulfill the requirement of translated version. The following is the example of the rejected data:

Datum 21:

SL: Maunya tidur-tiduran terus.

TL: It just lying down.

The translated version cannot be analyze since it doesn't fulfill the requirements of sending the source meaning. Furthermore, it doesn't fulfill the requirement of a full sentence.

Translation Method in 'Animal Around Us: Butterfly'

Seeing the findings of procedures in the 'Animal Around Us: Butterfly' storybook, it can be concluded that the translation method adopted by the translator according to Newmark's theory is semantic translation since the translator has given his effort in translating based on the context, not only literally. However, the translator still doesn't dominate the attention on the target language readers.

2. Seri Mengenal Hewan: Cerita Si Laba-Laba

Seri Mengenal Hewan: Cerita Si Laba-Laba is a short bilingual storybook published by Gema Insani. There are only twelve data in this book. Amon the data, it is found that the 
procedures found are literal, addition, modulation, reduction, transference, expansion and couplet. The most dominant procedures used is literal procedure.

\section{Literal}

This procedure is one of the most dominant procedures found. The translator translate the source language sentence and/or utterance literally. The following is the example of this procedure:

Datum 5

SL: Aku tidak boleh sombong karena memiliki serat sutera yang kuat.

TL: I must not be arrogant because of having the strong silk fibers.

Here in datum 5, target language sentence shows that there is not any change done. It is just translating the source language sentence. The similar thing happens to the following datum:

SL: Kawan, semua keunikan laba-laba diciptakan oleh Allah Ar-Rahmaan.

TL: Friends, all of spider uniqueness are created by Allah The Most Gracious.

As the previous example, this sample also doesn't show any changes to the translated version. Though there is a phrase showing the character of the God, the translator keeps it literally translated.

\section{Addition}

There are two addition procedure found among the data. In translating the source language the translator uses this procedure frequently. The following is the example of the procedure found in the data:

Datum 6

SL: Kami makhluk yang kecil dibanding hewan berbisa lain.

TL: We are really smaller creatures than other poisonous animals

In datum 6 , the translated version has additional word 'really'. Probably, the translator wants to emphasize more on the word small. Besides, in the word 'small' itself, inflectional morphem -er is also add.

Datum 3

SL: Tubuhku berbuku-buku atau disebut arthropoda.

TL: My body is knuckled or it is called arthropod.

The next datum shows that the translator adds the word 'it' in the translated version. The possibility is that the translator wants to give stress on the previous clause.

\section{Reduction}

The same with the addition procedure, reduction procedure is also found at the same number.

Datum 4:

SL: Ternyata kami memiliki sepasang rahang bertaring besar dan alat bantu mulut seperti tangan bernama pedipalpus

TL: In fact, we have a pair of big tusk jaws and a device that is called pedipalpus.

The example shows us that alat bantu mulut in source language sentence is translated as 'a device'. The translator chooses not to translate mulut. Another datum presenting reduction procedure is datum number 8 :

SL: Wah, bagaimana kami makan ya?

TL: How do we eat?

There are two words having reduction in the source language version. The first source language word wah is an interjection showing surprise. The second untranslated word is $y a$.

\section{Modulation}

As Reduction and addition, there are also two data included as modulation. The following is the example of modulation found:

Datum 9 
SL: Untuk menangkap serangga, jenis laba-laba dapat menginjeksi melalui sepasang taring.

TL: To snare an insect, we injects poison through our tusks.

In the example, the phrase jenis labalaba is translated as 'we'. The translator changes the point of view of the story teller. On the source language, the author posits herself as the third person while the translated version shows that the story teller is the first person.

\section{Transference}

There are only one transference procedure found here. It is in datum 1:

SL: Assalamualaikum, Kawan....

TL: Assalamualaikum, friends....

Here, the translator doesn't change or translate the Assalamualaikum from the source language. Even it is originally Arabics, the translator let it be as the original one. It is different to the previous case where the translator changes Ar-Rahmaan (Arabics word mentioning one of the character of The God) is translated literally into English.

\section{Expansion}

It is found that there are one datum showing the expansion. It is datum 12:

SL: Serat sutera itu dihasilkan dari kelenjar yang disebut spinneret yang berada di bagian belakang tubuh kami.

TL: The silk fibers are produced from a gland which is called spinneret. It is in the back of our bodies.

The translated version indicates the expansion by expanding one sentence into two sentences.

\section{Couplet}

Beside single procedures found in the data, there is also couplet or combination of two procedures in one place as shown in datum 11:
SL: Tubuhku bagian depan yang disebut prosoma adalah gabungan kepala dan dada.

TL: My front body is called prosoma. It consists of head and breast.

The translated version shows that there is shift procedures by changing noun phrase and adjectival phrase at the beginning into one full sentence and make the next part into another full sentence. At the same time, the expansion procedure is also done by expanding one sentence into two.

\section{Julie Di Peternakan}

'Julie di Peternakan' (Wilderode, 2006) storybook is different to 'Seri Mengenal Hewan: Cerita Si LabaLaba'. 'Julie di Peternakan' is a quite long bilingual storybook. Besides, among the three storybook analyzed in this research, this book is also different since the source language is English, while the target language is Bahasa Indonesia. There are 89 data in the book. Among the data, there couplet, literal, addition, reduction, modulation, cultural equivalent, shift, synonymy, expansion procedures are found. Of all the procedures, literal is the most dominant among them.

\section{Literal}

As mentioned earlier, literal procedure is the most frequent procedure being used by the translator. Of 89 data, there are 28 data belongs to this category. The following datum is the example of the category:

Datum

SL: "Good Morning, Sir. What are you doing?" asked Julie.

TL: "Selamat pagi, Pak. Bapak sedang apa?" tanya Julie.

Here, the translated version has only the literal translation without any other 
changes. Another example can be seen in datum 8:

SL: "Can I help you?" asked Julie.

TL: "Bisa aku bantu, Pak?" tanya Julie.

There is no changes found in the target utterances and/or sentence since it is only translated literally. The longer example can also be seen in the following:

SL: "Can you take care of him? You have to give him fresh hay and brush him a bit. You're not scared, aren't you?" asked Mr. Peter.

TL: "Bisakah kamu mengurus dia? Kamu harus memberinya jerami segar dan menyikatnya sedikit. Kamu tidak takut, bukan?" tanya pak Peter lagi.

Though the datum is relatively long enough, there is no indication that there is any changes made by the translator.

\section{Modulation}

Beside literal procedure, there are some numbers of procedures used by the translator. One of some procedures frequently used is modulation. It is found that there are thirteen data are categorized as modulation. Datum number 4 as the following:

SL: Julie liked going to the farm because it's full of surprises!

TL: Julie sangat senang pergi ke peternakan karena di sana banyak sekali kejutan!

In datum 4 , the translator translated the sub-clause 'it's full of surprises!' as ' $d i$ sana banyak sekali kejutan'. Rather than using the literal translation penuh kejutan, the translator prefers using what is written above. Full of surprise must have many surprise in it. Thus the translator chooses to use the other parole to convey the message since the meaning of the literal version and what is written are close enough. Besides, the effect caused by the two choices might be the same.
Another example can also be seen in datum 35:

SL: But he broke the egg.

TL: Tetapi telurnya pecah.

By having the translated version above the translator choose another way to say that the eggs is broken and the one braking the eggs is Boy the dog. In the source language, the subject is the dog shown by the pronoun 'he' which refers to Boy. While in the translated version, the subject is the egg. The meaning of the sentences is still the same.

\section{Addition}

Addition procedure found in the data is at the same number as modulation i.e. thirteen data. The example of the data is as the following:

Datum 2

SL: Her mother had told them to buy some fresh eggs.

TL: Ibu Julie menyuruh mereka membeli telur ayam yang segar dari pak Peter.

The translated version has an addition, ie Pak Peter which was not mentioned in source language. Where Julie had to buy the eggs had implicitly said in the previous sentence where Julie intended to go: Mr. Peter's house. However, the translator chooses to add the purposed person to buy the eggs. We can see another example in datum 15:

SL: Suddenly Boy ran inside the pen, barking.

TL: Tiba-tiba, Boy berlari ke dalam kanding sambil menggonggong.

The translator adds the word sambil in the translated version to show the correlation between the first action (ran inside the pen) and the second action (barking). There are some other additions which has the same function.

\section{Reduction}


There are ten data indicated as reduction procedure in the book. The example of data is as the following:

Datum 7

SL: "Hi Julie, I am just trying to fix this old tractor," said Mr. Peter with his hand covered in oil.

TL: "Hi Julie, sedang memperbaiki traktor tua ini," jawab pak Peter dengan tangan berlumuran oli.

Here in this datum, the translator doesn't translate 'I'm just'. He omits the words and directly goes to part of action as the answer to Julie's question. The reduction can also be seen in datum 13:

SL: A bunch of chickens and chicks were pecking the ground looked for their feed.

TL: Sekumpulan ayam dan anaknya sedang mematuk-matuk tanah mencari makan.

In the translated version, possessive pronoun 'their' is not translated and omitted. Probably, the translator considers it implied in the sentence.

\section{Cultural Equivalent}

There are two data included in this category. They are data 14 and 19 . Datum 14 will be the example here:

SL: "Cluck, cluck..." Julie cooed as she opened the pen

TL: "Kur, kur..." suara Julie sambil membuka pintu pagar.

The utterance/dialogue in source language indicates that it is the cultural word where some culture has their own way in calling hen/chicken in order to feed or call them. The translator uses the cultural equivalent "Kur, kur..." to be the equivalence of "Cluck, cluck..."

\section{Shift}

There are also shift procedure done by the translator in this storybook. There are four data categorized as the shift procedure here. One example of the shift is as the following:
Datum 18

SL: They all ran around, clucking.

TL: Semua ayam berkotek sambil berlarian.

The translator translate 'they' into 'ayam'. There is a shift from pronoun in source language into noun in target language.

\section{Synonymy}

There are only one synonymy procedure in this book. It is the datum number 23

SL: Finally Boy came to Julie.

TL: Akhirnya Boy menghampiri Julie.

The word "came" in SL is translated into 'menghampiri' in TL. The word 'menghampir 'will be 'getting closer' if it is retranslated into english. It has close meanign to 'came'. It can be said that it is the synonymy.

\section{Expansion}

As synonymy, expansion procedure is also one datum in the book. The datum considered to this category is datum number 75

SL: She dragged walked out, brushing hay off from her clothes.

TL: Kemudian Julie keluar dari kandang dengan sedih sambil membersihkan bajunya dari jerami.

The words 'dragged walked out' in the source language are translated elaborately by the translator into Kemudian Julie keluar dari kandang dengan sedih. It is done probably to give clearer meaning of the words when translated into the target language.

\section{Couplet}

Like the precious storybooks, in this book, there are also some couplet or combination of procedures. There are sixteen data concluded as this category. The example is as the following: Datum 3: 
SL: They said hello to the cows that were enjoying the fresh grass.

TL: Dalam perjalanan, Julie dan Boy menyapa sapi-sapi yang sedang menikmati rumput segar.

There is a combination between addition and modulation strategy here in this datum. The addition can be seen in the addition of the adverbial phrase 'dalam perjalanan.' Whilst the modulation occurs in the translation of 'said hello' into 'menyapa'.

\section{Error datum}

Among all the data, there are one datum which cannot be used to analyze. It is datum number 69.

SL: He was awed by Julie's diligence.

TL: Dia heran dengan ketekunan Julie. By translating 'he was awed' into 'dia heran', the translator changes the meaning. In the source language, $\mathrm{Mr}$. Peter which was referred as pronoun 'he' had a very positive amazement of what Julie had been doing. Whilst one 'he' translated version, the using of the word 'heran' indicates a bit negative thing happens.

\section{Translation Method}

We can see that the translator has tried to give some ease to the target language readers by some procedures. However, the data shows that the method used dominantly is semantic since has used context in helping her in translation process, yet the orientation mostly goes to the source language.

\section{CONCLUSION}

From the analysis, there are several conclusions can be taken from this research. The first one is that there are some procedures which frequently used. They are literal, modulation, shift, addition and reduction. It doesn't mean that the other procedures cannot be used. It is only based on the data found.
The second conclusion is that the most dominant procedure used in all storybooks is literal. It is taken that form the first book, there are nine of 35 . The second book gives three of twelve data. Whilst the third book donates 28 data of 89 data.

The last one that can be inferred from this research is that all the translation of the book still used semantic method. Though the translators have given their effort on giving some ease to the target readers, the data shows that the focus orientation is still on the source language text.

Of all the many good translation, there are found a very small number of error on the translation. The error is mostly because the shift of meaning. However, there must be a further research on the quality of translation of bilingual storybooks since it is used to attract first learners to read.

\section{REFERENCES}

Emzir. (2010). Metodologi Penelitian Kualitatif: Analisis Data. Jakarta: Rajawali Press.

Haryani, J. (2010). Seri Mengenal Hewan: Cerita Si Laba-Laba. Jakarta: Gema Insani Press.

Hoed, B. H. (2005). The Profession of Translator in Indonesia: Some Notes of Future Development. In International Conference: Translation \& Interpreting Studies in Indonesia.

Newmark, P. (1988). A Textbook of Translation. Text. Prentice Hall. https://doi.org/10.1017/CBO97811 07415324.004

Sasongko, S. G. (2007). Animal Around Us: Butterfly. Jakarta: Bestari Buana Murni.

Sundari, H., \& Febriyanti, R. H. (2016). Translation techniques and translation competence in translating informative text for 
indonesian EFL learners. Scope:

Journal of English Language

Teaching, 1(1), 17-28.

Titscher, S. (2009). Metode Analisis

Teks dan Wacana, (Terjemahan

Gozali dkk.). Yogyakarta: Pustaka Pelajar.

Wilderode, M. V. (2006). Julie di Peternakan [diterjemahkan oleh Rara Tanjung Hidayat]. Jakarta: Erlangga for Kids.

Wuryanto, A. (2005). Translation Procedures in the Translation of Scientific Terms in Textbooks. Materi. In International Conference: Translation \& Interpreting Studies in Indonesia. Jakarta. 